\title{
Vegetarian and vegan rights in Europe: chickening out or egging them on?
}

\author{
Maureen O’Sullivan García \\ National University of Ireland, Galway
}

Received: August 2020

Accepted: November 2020

Cita recomendada. O' SULLIVAN García, M., Vegetarian and vegan rights in Europe: chickening out or egging them on?, dA. Derecho Animal (Forum of Animal Law Studies) 11/4 (2020). - DOI https://doi.org/10.5565/rev/da.517

\begin{abstract}
The recognition of vegetarianism as a protected belief under equality legislation in the UK was denied by an employment tribunal judge in 2019. The judge in question treated vegetarianism as if it were frivolous and whimsical and compared it negatively with veganism. The following year he recognised veganism as a protected belief, which diverges from the norm of protecting both of these beliefs under the same legislative provisions. This article examines a selection of European cases starting in Ireland in the late nineteenth century in which vegetarianism was familiar, respected by eminent courts and protected without much fuss. The purpose is to demonstrate that the tribunal judge erred and that the pending appeal should be successful, failing which legislative intervention may be necessary.
\end{abstract}

Key words: Vegetarian; vegan; European Convention on Human Rights; equality legislation; UK; Ireland.

Resumen - Derechos de los vegetarianos y veganos en Europa: ¿rechazarlos o aceptarlos?

El reconocimiento del vegetarianismo como una creencia protegida bajo la legislación de igualdad en el Reino Unido fue denegado por un juez de un tribunal laboral en 2019. El juez en cuestión trató el vegetarianismo como si fuera frívolo y caprichoso y lo comparó negativamente con el veganismo. Al año siguiente reconoció el veganismo como una creencia protegida, lo que difiere de la norma de proteger ambas creencias bajo las mismas disposiciones legislativas. Este artículo examina una selección de casos que comenzaron a finales del siglo XIX en los que el vegetarianismo era familiar, respetado por tribunales eminentes y protegido sin mucho alboroto. El propósito es demostrar que el juez del tribunal incurrió en error y que la apelación pendiente debería ser exitosa, de no ser así, puede ser necesaria la intervención legislativa.

Palabras clave: Vegetariano; vegano; Convención Europea de Derechos Humanos; legislación de igualdad; Reino Unido; Irlanda. 


\section{Introduction}

This article gives an overview of the law relating to vegetarian and vegan rights in Europe and focuses on the UK and Ireland. It examines themes such as the unpredictability of rights recognition in different jurisdictions and shows that whilst European institutions set harmonised and universal standards, national courts and tribunals do not always follow suit in their interpretations. It is important to note that in some jurisdictions, equality law which hails from the European Union covers religion alone and not secular beliefs ${ }^{1}$ and whether courts or tribunals would extend the law in this area is uncertain. Courts may then have recourse to the Council of Europe's Convention, by which all Member States of the EU are bound, rather than the EU's Charter providing that tribunal rules so permit and if the judges are well versed in this area. What this article will show is that rights in this realm are a minefield: there are multiple sources of law and a myriad of potential fonts too. Even comparing two common law jurisdictions such as the UK and Ireland shows significant differences in sources and interpretations of the law. This makes for a dynamic and unpredictable legal landscape. However, the rights of vegetarians have been uncontroversial up until recently and so the divergence by a tribunal of first instance merits scrutiny.

The two cases in question on the issues of vegetarianism and veganism were heard by the same judge, Robin Postle in an Employment Tribunal in Norwich in 2019 and 2020, respectively. The cases examined whether vegetarianism and veganism are protected beliefs under equality legislation in the UK. The verdicts turned out rather differently. In the case of the former, the Tribunal refused to accept that vegetarianism amounted to any more than "opinion or belief" and in the latter case, veganism was accepted as a protected ethical belief. ${ }^{3}$ This article will first conduct a study of cases which recognised vegetarianism (and veganism) in the UK, Europe and Ireland. It will then scrutinise relevant legislative provision and will lastly evaluate the aforementioned tribunal cases in a historical light.

\section{Judicial origins of vegetarian rights}

The judicial recognition of vegetarianism stretches back to the late nineteenth century to a case in the Irish Court of Appeal before independence. The term "veganism" had not yet been coined so it is safe to say that vegetarianism was an umbrella term which covered dietary practices including or excluding dairy products, eggs and honey. Of note is that this case also pre-dated the legislative framework of human rights: in 1898, Ireland was still a colony under Britain's yoke, it did not have a written constitution and none of the international human rights framework would be in place for another fifty years at least. Nevertheless, in the case of In re Cranston, Webb \& Oldfield,$^{4}$ three of four judges recognised vegetarianism as a belief worthy of protection in the context of charitable donations to two vegetarian societies based in London and Manchester. This case was an appeal from a Court of Chancery case in which the judge, Porter M.R., had also recognised vegetarianism.

In re Cranston, ${ }^{5}$ the gift had been made to promote the cessation of the killing of animals for food. The principal point of contention between the parties was whether the charitable purpose of the societies should be assessed subjectively, according to the donor's belief or objectively according to some other criteria. The judges did not waver from the subjective approach as to do otherwise would involve an evaluation of a belief system: in this case, vegetarianism. The affirming judges, Walker L.J., Lord Ashbourne L.C. and Fitzgibbon L.J. referred to the societies' own description of their aims in order to assess their charitable purposes. Rather than attempting an objective assessment of vegetarian objectives, they accepted them without further ado.

What is interesting in the context of the cases which follow is that the societies' descriptions do not appear to encourage fully-fledged vegetarianism but, rather, focus on the plant kingdom and an avoidance of cruelty to animals. Their advocacy, effectively, is of what we now know as veganism. Given that people still sometimes describe themselves as lacto-, ovo- or "strict" vegetarian, this suggests that there exist vegetarians who are entirely plant based and who also care about animals just as much as people who adopt a more nuanced label. Courts do not generally distinguish the two beliefs so any deviance from this path is exceptional.

In another Irish case from the early twentieth century, O'Hanlon $v$ Logue ${ }^{6}$ the facts once again concerned whether charitable bequests were to be decided subjectively or objectively: this time in relation to

\footnotetext{
${ }^{1}$ In Ireland, the Equality Acts 2000-2015 cover religion but not ethical belief.

${ }^{2}$ Conisbee v Crossley Farms Ltd Unreported 6 September 2019 (ET (Norwich)).

${ }^{3}$ Casamitjana v League Against Cruel Sports unreported 3 January 2020 (ET (Norwich)).

${ }^{4}$ [1898] 1 I.R. 431

5 [1898] 1 I.R. 431.

${ }^{6}$ O'Hanlon v Logue [1906] 40 ILTR 78.

72 Derecho Animal. Forum of Animal Law Studies, vol. 11/4
} 
religious institutions. At the time, English law favoured the former approach and the societies would be evaluated upon their own principles alone. Two of the judges compared the position of bequests promoting vegetarianism which had already been recognised with religious ones and they opined that the treatment should not differ. Palles, LCB observed that the vegetarian and anti-vivisection cases in England had established that the question should be decided subjectively, in accordance with the standpoint of the society in question. ${ }^{7}$ Fitzgibbon L.J. confirmed that given that bequests for the promotion of vegetarianism had been held to be charitable objects, so too could bequests for the celebration of religious rites. ${ }^{8}$ Vegetarianism was clearly recognised as an established and uncontroversial belief system by the contemporary judiciary.

It has been clarified by O'Halloran that the subjective approach is no longer employed in the UK, ${ }^{9}$ but it is still followed in Ireland. ${ }^{10} \mathrm{~A}$ former Chief Justice of Ireland, Keane J. (as he then was) observed in Re the Worth Library ${ }^{11}$ that the intention of the testator would prevail so long as the charitable object had legal recognition. The judge also stated that the testator's opinion that the gift had a public utility did not have to be shared widely and he gave an example of vegetarianism to highlight this point. Providing that the gift was "not illegal, irrational or contra bonos mores"12 the court would enquire no further. Not everyone may agree with vegetarianism in the court's view but that fact was irrelevant.

\section{International and European legislation - and national quirks}

Since the enactment of the Universal Declaration of Human Rights, the ambit of human rights has expanded. Articles 18 and 27 of the International Covenant on Civil and Political Rights, which derives from the Universal Declaration are enforceable and they protect religious freedom and also freedom of thought and conscience. This Declaration is at the root of human rights law in Europe, and it inspired the European Convention on Human Rights which has shaped much of the jurisprudence in this area within its large jurisdiction of 47 states. Over time, the interpretation of matters relating to conscience has expanded and it is here that the recognition of vegetarian and vegan rights has occurred.

The Convention, as an instrument of international law, is binding in monist states but not so in dualist states which have to pass enabling legislation in order for it to become law. Long before the UK or Ireland, both of which are dualist states domesticated the Convention, its provisions became mandatory due to their membership of the (present) EU. Article 9 of the Convention provides the following:

1. Everyone has the right to freedom of thought, conscience and religion; this right includes freedom to change his religion or belief, and freedom, either alone or in community with others and in public or private, to manifest his religion or belief, in worship, teaching, practice and observance.

2. Freedom to manifest one's religion or beliefs shall be subject only to such limitations as are prescribed by law and are necessary in a democratic society in the interest of public safety, for the protection of public order, health or morals, or the protection of the rights and freedoms of others.

The interpretation of this Convention in relation to vegetarians and vegans is laid out on the Council of Europe website ${ }^{13}$ and their beliefs are among those protected.

Now that Britain has left the EU, the status of the ECHR will no longer be assured but other differences existed prior to Brexit. The purpose of this exposition is to show how difficult it can be to harmonise a right and to suggest that more detailed legislation may be needed. Britain does not have a written constitution and parliament is supreme. That is not to say that there is no constitution as such. Constitutional law does exist in the form of conventions, customs and an array of sources which have not been gathered together in one document.

The European Convention on Human Rights was domesticated in the UK in 1998 in the form of the Human Rights Act and laws must be read with this in focus. However, there have been repeated threats over the years to retreat altogether from the European Convention and Court of Human Rights and to replace the Convention with a bill of rights ${ }^{14}$ although for now, the Human Rights Act 1998 still stands. When debates of this nature come to the fore it leaves clear the fact that any such moves could lead to a different regime and this may or may not favour the status of vegetarians and vegans.

\footnotetext{
${ }^{7}$ O'Hanlon v Logue [1906] 40 ILTR 78.

${ }^{8}$ O'Hanlon v Logue [1906] 40 ILTR 78.

${ }^{9}$ The approach changed in Re Hummeltenberg [1923] 1 Ch. 237.

${ }^{10}$ O'HALLORAN, K., Charity, the Law and Social Need, in Dublin University Law Journal, 23/1 (2001) 97-119.

11 [1994] 1 I.L.R.M. 161.

12 [1994] 1 I.L.R.M. 161 at 193.

${ }^{13} \mathrm{https} / / /$ www.echr.coe.int/Documents/Guide Art 9 ENG.pdf, p. 31 (accessed May 13, 2020).

${ }^{14} \mathrm{http}: / /$ www.bbc.co.uk/newsbeat/article/32692758/human-rights-act-versus-a-british-bill-of-rights, (accessed August 14, 2020).
} 
If we compare the UK and Ireland, the latter has a written constitution with an array of enumerated, or named rights such as the right to life, education, property, religion and family. It also protects freedom of thought and opinion. Additionally, it has judicially recognised, unenumerated or unnamed rights which is not a closed class (and therefore potentially open to vegetarians and vegans). ${ }^{15}$ The European Convention on Human Rights was passed into Irish law in the form of the European Convention on Human Rights Act 2003 but it ranks beneath the Constitution in terms of its place in the hierarchy meaning that if there is a clash, the Constitution trumps the Convention. Does this mean that the Convention has a double face in Ireland: a domesticated side and a European one, meaning that one could invoke the European version of the Convention if reliance on its Irish enactment was unsuccessful - or vice versa? Clarke, C.J. clarifies, albeit in a different subject matter, that there is an asynchronous manifestation of these rights, ${ }^{16}$ so they do have a dual aspect.

EU Member States can rely on the EU Framework Equality Directive of 2003 which has given rise to further equality legislation among member states. The Charter of Fundamental Rights which came into force with the Treaty of Lisbon may also be a source of rights. However, Harvey observes that it is more likely that the ECHR will be invoked in some cases of discrimination, given the court's experience in this matter. ${ }^{17}$ In areas of the law such as human dignity, the Court of Justice of the European Union is expanding its rights regime, such as the delineation of human dignity, based on the EU Charter rather than the European Convention. ${ }^{18}$ However, this will no longer apply in the UK, meaning that there may be divergences relating to the protection offered over time.

Furthermore, equality legislation has been passed in both jurisdictions and this prohibits discrimination on several grounds, including religion. However, this passage into national law has not been uniform and, for instance, in Ireland ethical beliefs have not been denominated as protectable. Where the motivation for vegetarianism arises in the context of a dietary practice associated with religion, it would, in all likelihood, be protected but if its premises were purely secular, it may not.

Both jurisdictions have bodies that act as guardians of these rights ${ }^{19}$ and whilst they opine that beliefs such as vegetarianism and veganism are protected, the judgments of courts and tribunals are not now ad idem on the matter. As the UK is a considerably bigger jurisdiction, this issue has already been encountered and the Equality and Human Rights Commission recognises vegetarianism and veganism as protected beliefs, meaning that no discrimination is allowed. This does not necessarily bind, is not uncontroversial and in any case, the future of this body may change in the absence of EU oversight or direction. Moreover, the designation and recognition of such rights may also cause meat eaters to assert rights that clash or compete ${ }^{20}$ but whether courts and tribunals would be convinced remains to be seen. Non-meat eaters may need to tread with caution.

\section{European and national case law}

In the UK and European Court of Human Rights, several cases recognise ethical beliefs as encompassing vegetarianism and veganism. In $H v$ the United Kingdom ${ }^{21}$ the claimant was a prisoner and a requirement of his incarceration was that he would be employed in a print works. Dyes which had been tested on animals were used and he claimed that this infringed his vegan beliefs. He refused to work there and was punished more than once. The ECtHR acknowledged that both the British government and the Commission recognised veganism as a protected belief ${ }^{22}$ within the ambit of conscience and personal beliefs. These beliefs are not absolute, of course, and must be weighed up with any contrary considerations. In this case, the requirement to work was in place so as to maintain an orderly environment in the prison. The prisoner was not successful in his claim but veganism was recognised as protectable.

\footnotetext{
${ }^{15}$ Although, the Chief Justice, Mr. Frank Clarke, has recommended that these rights be reconceptualised as "derived rights", or rights which derive from an existing constitutional right in Friends of the Irish Environment v. The Government of Ireland [2020] IESC 49. ${ }^{16}$ Ibid.

${ }^{17}$ HARVEY, B., Guide to Equality and the Policies, Institutions and Programmes of the European Union https://www.ihrec.ie/app/uploads/download/pdf/guide_to_equality_and_the_policies_institutions_and_programmes_of_the_eu.pdf, (accessed July 30, 2020).

${ }^{18}$ O'Sullivan notes the cross-referencing between the European Patent Office Boards and the Court of Justice of the European Union in the realm of human dignity and patent law. O'SULLIVAN, M., Biotechnology, Patents and Morality: A Deliberative and Participatory Paradigm for Reform (London and New York, 2019) 45-50.

${ }^{19}$ In the UK, the body is called the Equality and Human Rights Commission whereas in Ireland, it is the Irish Human Rights and Equality Commission.

${ }^{20}$ In an article relating to the case Jewish Liturgical Association Cha'are Shalom Ve Tsedek v France (2000) 9 BHRC 27, ECHR, in which a challenge was brought to the ban on halal slaughter in France, Cohen opines that the ECtHR regards meat as a protected good. COHEN, G., Article 9 of the European Convention on Human Rights and protected goods, in Ecclesiastical Law Journal 12/2 (2010) $180,184$.

${ }^{21}$ [1992] 16 EHRR CD 44. This case is also referred to as $W v U K$.

$22 \mathrm{https} / /$ hudoc.echr.coe.int/fre\# \{\%22itemid\%22:[\%22001-1503\%22]\}, (accessed May 7, 2020).

74 Derecho Animal. Forum of Animal Law Studies, vol. 11/4
} 
Two cases from the European Court of Human Rights leave in no doubt that vegetarianism is a protected belief under Article 9. Both cases involved prisoners who adopted vegetarian diets because of their religion, as they were Buddhists. A practice associated with religious belief in the ECHR falls under the protection of religion which, especially if dealing with a recognised and established faith, is uncontroversial. This arose in cases taken in Poland and Romania in 2010 and 2013 respectively.

In the first case, Jakobski $v$ Poland $^{23}$ the prisoner had requested vegetarian food and as the prison did not provide this diet, Jacobski sued and was awarded a sum of $€ 3,000$ by way of compensation. The rationale of the case was that while the right is not absolute and must be balanced with other considerations, the request for vegetarian food would not have placed an undue burden on the prison and it therefore should have been provided.

Within a short few years, a comparable case was heard and similarly decided. In Vartic v Romania ${ }^{24}$ the prisoner requested a vegetarian diet and the prison did not oblige. Again, Vartic sued successfully and was awarded $€ 3,200$ compensation. The reasons for refusing supplying a vegetarian diet must be genuine and not capricious or designed to punish.

There are other cases in the UK in which veganism has been recognised as a protected belief ${ }^{25}$ and there are obiter statements in the courts giving vegetarianism as a straightforward example of a protected belief. ${ }^{26}$ As this article has shown so far, vegetarianism is a familiar practice in the courts and it arose tangentially in a House of Lords decision. In $R v$ Secretary of State for Education and Employment and others ex parte Williamson ${ }^{27}$ vegetarianism was acknowledged as a protected belief. In the case which related to religious education and the disciplining of children, Lord Walker referred, albeit in an obiter statement, to vegetarianism as an instance of a non-religious belief falling with the protection of human rights law. ${ }^{28}$ His words were: "Pacifism and vegetarianism and total abstinence from alcohol are uncontroversial examples of beliefs which fall within article 9." Edge rightly observes that the case did not hinge on vegetarianism, ${ }^{29}$ however the purpose of the commentary is to show that vegetarianism has long been recognised as a belief system by the courts in an array of circumstances.

Polemic could potentially arise where vegetarianism is not mandatory within a belief system but is, rather, aspirational and where a failure to abide with the practice does not result in some sanction. Courts, however, tend not to delve into the nuances of religious belief and when they do, it can have a disruptive effect which destabilises the certainties under which minority groups live their lives. It can also result in appeals which more often than not restore the status quo.

There have been a number opinions as to whether vegetarianism should be protected by the Equality Act 2010, although none of these are binding. First of all, the Equalities and Human Rights Commission have affirmed its protected status in its guidance on religion and belief. ${ }^{30}$ In a subsequent communication from the then Government, this interpretation was contested so there is not universal agreement. However, this might be a failure to conceptualise vegetarianism and veganism accurately. There is a tendency to view it as a secular right but the cases show that it often arises as a practice associated with a religion. Records from Hansard indicate that Baroness Warsi viewed vegetarianism and veganism as cults whose inclusion in equality legislation was farcical. ${ }^{31}$ Her intervention is unfortunate in that it shows a lack of understanding of the multiple sources and depth of vegetarianism's importance in some belief systems.

It may be that more detailed legislation is needed when such cases arise and this might also help to iron out differences in interpretation between bodies such as the Equality and Human Rights Commission in the UK and some legislators who viewed the issue of whether vegetarians and vegans should benefit from the rights regime very differently. The judiciary may need to be better informed.

\section{Tribunals and beliefs}

\footnotetext{
23 [2010] ECHR 1974, [2011] Eq LR 197, 30 BHRC 417, (2012) 55 EHRR 8.

24 [2013] ECHR 1296.

${ }^{25}$ Casamitjana $v$ League against Cruel Sports Unreported 3 January 2020 (ET (Norwich)).

${ }^{26} R v$ Secretary of State for Education and Employment and others ex parte Williamson 2005 UKHL 15.

2005 UKHL 15.

${ }^{28}$ Ibid 55.

${ }^{29}$ EDGE, P., Vegetarianism as a protected characteristic: another view on Conisbee, in Law \& Religion UK (21 September, 2019) https://www.lawandreligionuk.com/2019/09/23/vegetarianism-as-a-protected-characteristic-another-view-on-conisbee/, (accessed August 28, 2020).

${ }^{30}$ Religion or Belief: A Guide to the Law https://www.equalityhumanrights.com/sites/default/files/religion-or-belief-guide-to-thelaw.pdf, (accessed August 28, 2020).

${ }^{31}$ On 23 March 2010 column 853.
} 
Other secular beliefs such as environmentalism have also been recognised by British tribunals, ${ }^{32}$ and these have a bearing on the development of the recognition - or otherwise - of vegetarianism and veganism as parameters are being established. Although veganism is understood as an ethical belief which prioritises animals, it is often bound up with other, overlapping beliefs such as religious dietary rules and, indeed, concern for the environment.

The recognition in Grainger plc v Nicholson ${ }^{33}$ might have tangential importance if the reason for the individual's veganism or vegetarianism is environmental. Moreover, this case has been cited in subsequent cases as setting standard salient criteria for recognition. These are as follows: the belief must be genuinely held; it should not merely be an opinion or viewpoint based on the present state of information available; it should concern a weighty and substantial facet of human life and behaviour; it must attain a certain level of cogency, seriousness, cohesion and importance, and; it must be worthy of respect in a democratic society, it must not be incompatible with human dignity or conflict with the fundamental rights of others. ${ }^{34}$

The principles laid down in Grainger have been reiterated in Hashman v Milton Park (Dorset) Ltd t/a Orchard Park ${ }^{35}$ and in this case the claimant successfully asserted that his abhorrence of fox hunting was a protected belief within UK law. The complainant was an anti-hunting activist and an active member of Hunt Saboteurs Association. Of note is that he was also a vegan which shed light on the depth of his beliefs regarding animal exploitation. In order to qualify as a belief, it must satisfy the test laid down in Grainger ${ }^{36}$ above. The judge found that Hashman's belief did satisfy the criteria, however, this decision was case-specific so not everyone who opposes fox-hunting would hold a protected philosophical belief.

\section{Vegetarianism going down a rabbit hole?}

It is surprising, therefore, that a judge of a tribunal in 2019 seemed to be unaware of the depth of the heritage of vegetarianism in the law. Not only did he disregard the recent European and UK cases in which vegetarianism had been deemed to be a protected belief: he also declined to acknowledge the views of senior and eminent judges who decided the matter differently in higher courts, back in the late nineteenth century and, indeed, more recently. One would hope that he was at least conversant with these cases but this may not have been true. The facts of Conisbee v Crossley Farms Ltd. ${ }^{37}$ are as follows.

Conisbee worked at a hotel as a waiter and he believed that animal cruelty is immoral. He had been derided in his workplace for this and had endured teasing from his workmates about his vegetarianism. This culminated in his being led to believe that his food had been spiked with meat - it remains unknown whether this was true or not. Conisbee brought tribunal proceedings against his employer under the UK's equality legislation, which emanates from the EU Framework Directive. He alleged discrimination on the ground of his vegetarianism and liability was denied.

The Tribunal assessed his claim on the aforementioned Grainger criteria. ${ }^{38}$ The tribunal acceded that the claimant's vegetarianism was genuine. His beliefs were worthy of respect in a democratic society and were not incompatible with human dignity nor in conflict with the rights of others. The tribunal portrayed vegetarianism as a lifestyle choice and that it did not concern human life and behaviour but, rather, that of animals and fish. Some of the reasoning appears distinctly odd.

In a preliminary hearing, the judgment of which is currently under appeal, the judge, Postle J. refused to accept that vegetarianism qualifies as a protected belief which attracts protection under the Equality Act 2010. This flies in the face of centuries of jurisprudence from much weightier courts, as outlined above. Postle J. grounded his reasoning on an application of Grainger plc and ors $v$ Nicholson, ${ }^{39}$ in which the rules for the recognition of a protected belief had been laid down. Whilst accepting that Conisbee's beliefs satisfied some of the criteria in that they were genuine and did not interfere with the rights of others, he nonetheless denigrated his vegetarianism as merely a superficial lifestyle choice rather than a profound belief. He opined that vegetarians could be fickle and change their diet after short intervals. As people were vegetarian for many different reasons, this showed that the belief system was not coherent. He contrasted this with veganism which he claimed was uniform in this domain. All vegans, he opined, were vegan for the same reason and therefore their beliefs were coherent and cogent.

\footnotetext{
${ }^{32}$ Grainger plc v Nicholson [2010] IRLR 4.

33 [2010] IRLR 4.

${ }^{34}$ Ibid.

35 [2011] ET/3105555/09 26 October 2011.

362010 ICR 360 (Brief 890).

${ }^{37}$ Unreported 6 September 2019 (ET (Norwich)).

${ }^{38}$ Grainger plc and ors $v$ Nicholson 2010 ICR 360 (Brief 890), op. cit.

392010 ICR 360 (Brief 890).

76 Derecho Animal. Forum of Animal Law Studies, vol. 11/4
} 
However, the conditions of coherence and cogency relate to the rationality of the belief itself rather than the behaviour of the practitioner. It would appear that the judge misunderstood the law. A case commentary in the IDS Employment Law Brief criticises this decision as a potential misunderstanding of the necessity for cogency and coherence, citing Gray v Mulberry Co (Design) Ltd. ${ }^{40}$ In this case, the judge explained incoherence as an inconsistent demonstration of the belief rather than a multiplicity of reasons by different people for assuming a particular belief. ${ }^{41}$ Furthermore, Cranmer and Russell heartily criticise the premise of this judicial enquiry as it involves courts in the task of questioning doctrine. ${ }^{42}$ In the early Irish cases such as Cranston, the judges specifically avoided engaging in this sort of exercise. Vegetarianism was portrayed by Postle J. as being frivolous ${ }^{43}$ and Cranmer and Sandberg reject the premise of the decision, affirming that Conisbee's convictions typify the characteristics found in most beliefs systems. ${ }^{44}$

The judge went on to contrast vegetarianism with veganism, holding that the latter adherents all hold their beliefs for the same reason unlike its depiction of the former. Edge criticises this conceptualisation and correctly claims that vegans also have a variety of reasons for their beliefs. Vegans hail from both atheist and religious traditions. ${ }^{45}$ Moreover, veganism predates Watson's taxonomic classification where it arises in religious traditions such as Jainism. An appeal has been lodged with the Employment Appeals Tribunal which is bound by precedent. ${ }^{46}$

\section{But veganism is protected by the same judge}

The very next year, the judge in Conisbee, Postle J found that "ethical veganism" qualifies as a protected belief in Casamitjana v League against Cruel Sports. ${ }^{47}$ In this case, Casamitjana worked for the League against Cruel Sports. He was a vegan but found out that his pension fund was linked to firms which tested on animals. He publicised the matter, was dismissed from his job and he subsequently took an action. The Tribunal applied the test in Grainger $^{48}$ and referenced the Equality and Human Rights Commission Code of Practice on Employment 2011 which details the five criteria essential to recognised philosophical beliefs. ${ }^{49}$ The claimant's behaviour was scrutinised ${ }^{50}$ and expert evidence from Dr. Jeanette Rowley of the Vegan Society was proffered. His underlying vegan principles were based on ahimsa, or refraining from doing harm. This is an ethical code in religions including Jainism, Buddhism and Hinduism although the claimant did not follow any of these religions. The foundation of his belief appears to have been secular. It was adduced in evidence that ethical veganism involves living in so far as possible without using animal products. ${ }^{51}$

The tribunal found in favour of the claimant, holding that "ethical veganism" is a belief and not merely viewpoint. The judge did not clarify why he added the adjective "ethical". Veganism, by definition, is an ethical belief system and practice and it is now unclear whether "veganism" simpliciter sets another standard. In a second suggestion that the judge erred in his application of the "cogent and coherent" belief criterion in the Conisbee case, it became evident that Casamitjana was not expected to always live by his principles and was permitted some flexibility. This appears heretical when judged by the standard set out in Gray v Mulberry Co (Design) Ltd. ${ }^{52}$ Unlike in Conisbee, Casamitjana's belief was found to preside at an intersection between human and non-human animal life and this was deemed to be significant. ${ }^{53}$ The parties settled the case.

\section{A tangled warren of outcomes?}

Most judges conflate vegetarianism and veganism as being under the same umbrella, so to recognise one and not the other does not follow a logical pattern. Moreover, Postle J. showed himself to be considerably more tolerant of deviations from the path of pious veganism in the Castmijana case than in Conisbee and one hundred per cent adherence to the belief was not expected. Moreover, the judge added the adjective "ethical"

\footnotetext{
402019 ICR 175, EAT.

${ }^{41}$ Case Comment: 'Religion or belief discrimination: vegetarianism not a protected belief' IDS Emp. L. Brief (2019) $118,17$.

${ }^{42}$ CRANMER, F., SANDBERG, R., A critique of the decision in Conisbee that vegetarianism is not "a belief", in Ecclesiastical Law Journal 22/1 (2020) 36, 47.

${ }^{43}$ Conisbee, (para 31).

${ }^{44}$ CRANMER, F., SANDBERG, R., op cit 45.

${ }^{45}$ EDGE, P., op cit.

${ }^{46} \mathrm{https}: / /$ www.edp24.co.uk/news/crime/solicitors-appeal-case-of-beccles-vegetarian-waiter-1-6329065, (accessed August 28, 2020).

${ }^{47}$ Unreported 3 January 2020 (ET (Norwich)).

48 [2010] ICR 360 EAT.

${ }^{49}$ In particular paragraphs $2.55-2.61$, particularly 2.59 .

${ }^{50}$ Para 22.7.

${ }^{51}$ Para 12.

522019 ICR 175, EAT.

${ }^{53}$ Para 35.
} 
to vegan, raising a question as to whether one can be a non-ethical vegan. This complicates the legal nomenclature and appears to contradict his obiter statements in Conisbee in which he stated that all vegans were vegans for the same reason. Yet, less than a year later he has further refined the terrain, recognising ethical vegans but suggesting in doing so that there may be other classes of vegans that are not ethical or even vegans who are unethical. The muddying of these waters was entirely unnecessary and unfortunate.

The fracturing in the application of European law is also highlighted by the fact that in Italy veganism was also recognised as an ethical belief in $2020 .^{54}$ This is despite the fact that there have been moves in the Italian parliament to jail parents who raise their children as vegans. ${ }^{55}$ It does show that much more education is necessary and that food should not be used as a weapon with which to discriminate against minorities. It also demonstrates that more legislative clarity is needed: the Council of Europe and the Equality and Human Rights Commission both interpret the Convention as protecting dietary rules related to religious and ethical belief but regrettably tribunals such as the Conisbee one feel free to disregard this, putting the victim through much trauma, time and expense in having to mount an appeal. Moreover, there is the uncertainty of the outcome in the absence of crystal clear legislative guidance.

\section{Conclusions}

The findings of this article are that more eminent judges are usually aware of the parameters of their role and are well versed in the frontiers of human rights. They do not seek to evaluate the beliefs of others, especially where such beliefs are not unknown in societal and legal circles. Some tribunal judges, however, do not appear to understand so well the constellation of rights and how they should be arbitrated. Training and education are clearly necessary and more detailed legislative provisions should be provided in order to indicate clearly the nature of the rights granted and the groups that they cover. Failing that, anomalous judgments such as Conisbee can occur and leave vegetarians in a worrisome situation: that discrimination against them is not illegal and their core beliefs can be infringed safe in the knowledge that they currently may have no recourse to legal remedies.

\footnotetext{
${ }^{54}$ Giudice del Lavoro - Tribunale di Bologna - sentenza n. 2359/2020 del 9 aprile 2020.

${ }^{55} \mathrm{https}: / / w w w . b b c . c o m / n e w s / w o r l d-e u r o p e-37034619$, (accessed August 14, 2020). 